\title{
MECHANISTIC AND KINETIC STUDIES OF HIGH-TEMPERATURE COAL GAS DESULFURIZATION SORBENTS
}

\author{
Susan Lew \\ Maria Flytzani-Stephanopoulos \\ Adel F. Sarofim \\ Quarterly Technical Progress Report No. 9 \\ November 1990
}

Prepared for:

U.S. Department of Energy

Pittsburgh Energy Technology Center

Pittsburgh, Pennsylvania

Technical Project Officer - G.E. Staats

Grant No. DE-FG22-88PC88927

by

Massachusetts Institute of Technology

Department of Chemical Engineering

Cambridge, Massachusetts

"US/DOF. Patent Clearance is nol required prior to the publication of this document"

DISTRIBIJTION OF THIS DOCUMENT IS UNLIMITL.

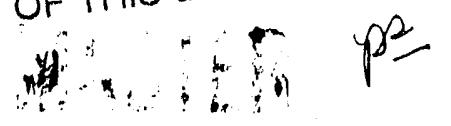


During this quarter work on the reduction of zinc titanate materials was written-up as a journal article and submitted for publication. The manuscript of this paper, entitled "The Reduction of Zinc Titanate and Zinc Oxide Solids", is hereby submitted to the DOE as part of our quarterly report.

On the basis of the completed parametric studies of reduction and sulfidation (effects of $\mathrm{H}_{2}, \mathrm{H}_{2} \mathrm{O}$, see quarterly reports $\# 7,8$ ), $\mathrm{ZnO}$ and $\mathrm{Zn}$-Ti-O materials were evaluated in terms of reduction-sulfidation kinetic differences. Comparative Arrhenius plots of the initial reduction and sulfidation rates are shown in Figure 1 for the sorbents $\mathrm{ZnO}, \mathrm{Z2T}$-a $(2 \mathrm{Zn}: 1 \mathrm{Ti})$ and $\mathrm{Z} 2 \mathrm{~T} 3-\mathrm{a}(2 \mathrm{Zn}: 3 \mathrm{Ti})$. The reduction rate is shown for a gas containing (mol) $10 \% \mathrm{H}_{2}-3 \% \mathrm{H}_{2} \mathrm{O}-87 \% \mathrm{~N}_{2}$, while sufidation is for $2 \% \mathrm{H}_{2} \mathrm{~S}-98 \% \mathrm{~N} 2$. The point at which the initial reduction rate becomes faster than sulfidation rate is 848,872 and $942^{\circ} \mathrm{C}$, respectively, for $\mathrm{ZnO}, \mathrm{Z2T}$-a and Z2T3-a. Therefore, $\mathrm{Zn}$-Ti-O solids can be used for the desulfurization of coal-derived fuel gas at higher temperatures than single $\mathrm{ZnO}$. For sorbent $\mathrm{Z} 2 \mathrm{~T} 3$-a, the desulfurization temperature can be 94 degrees Celcius higher than for $\mathrm{ZnO}$. Moreover, as reported in the previous quarterly report (DOE/PC/88927-8) the presence of $\mathrm{TiO}_{2}$ largely suppresses the gross morphological effects observed on $\mathrm{ZnO}$ particles as a result of sulfidation in the presence of high hydrogen concentrations. The appearance of macroscopic cracks and the formation of of fine particles of $\mathrm{ZnS}$ by the elution and reaction, respectively, of zinc vapor, $\mathrm{Zn}(\mathrm{g})$, with $\mathrm{H}_{2} \mathrm{~S}(\mathrm{~g})$ limit the application of single $\mathrm{ZnO}$ to lower $\mathrm{H}_{2}$-containing gas streams and lower temperatures. Another issue is the loss of surface area (sintering) by $\mathrm{H}_{2} \mathrm{O}$. While this was similar for both $\mathrm{ZnO}$ and $\mathrm{Zn}$-Ti-O materials, (see Report \#DCE/PC/88927-7), it is alleviated for zinc titanates by the redispersion (surface area increase) observed upon sulfidation of these sorbents.

These observations offer interesting possibilities for reactor design. Desulfurization in a fixed-bed reactor will lead to zinc loss. Because of the gradient in $\mathrm{H}_{2} \mathrm{~S}$ concentration as a function of sorbent bed axial position, a portion of the sorbent bed will be in contact with a $\mathrm{H}_{2} \mathrm{~S}$-free reducing gas. In this part of the bed, zinc loss can occur. On the other hand, desulfurization in a fluidized bed reactor offers the possibility of eliminating zinc loss. The disadvantages of this reactcr configuration, however, are lower $\mathrm{H}_{2} \mathrm{~S}$ removal efficiency (due to bubbling) as well as the fact that the vapor phase reaction between $\mathrm{H}_{2} \mathrm{~S}$ and $\mathrm{Zn}$ will produce fines and will lead to sorbent elutriation and loss. For the fluidized bed reactor, mixed $\mathrm{Zn}$-Ti oxides would still be preferable as sulfur sorbents over $\mathrm{ZnO}$ because of lower particle disintegration (due to crack formation) and fines production.

Regeneration of Bulk Zn-Ti-O Sorbents In order for $\mathrm{Zn}$-Ti-O solids to be used commercially for the desulfurization of hot fuel gases, the sulfided solids must be regenerable. To determine the regenerability of Zn-Ti-O solids and their sulfidation performance after regeneration, two cycles of consecutive sulfidation-regeneration were performed with $\mathrm{ZnO}$ and $\mathrm{Z} 2 \mathrm{~T}$-a. The results are shown in Figure 2 in terms of the dimensionless weight $\mathrm{W} / \mathrm{Wo}$ (where $\mathrm{W}$ is the instantaneous and Wo is the initial weight of the solid) versus the reaction time. Prior to the first cycle, the solids were reduced in $10 \%$ $\mathrm{H}_{2}-90 \% \mathrm{~N}_{2}$ for seven minutes. The partially reduced solids were then sulfided in $2 \% \mathrm{H}_{2} \mathrm{~S}$ - 
$98 \% \mathrm{~N}_{2}$. After sulfidation, regeneration was performed in air $\left(21 \% \mathrm{O}_{2}-79 \% \mathrm{~N}_{2}\right)$. All reactions were performed at $650^{\circ} \mathrm{C}$. The more rapid decrease in sulfidation rate of sorbent $\mathrm{Z} 2 \mathrm{~T}-\mathrm{a}$, seen in Figure 2b, is attributed to the presence of non-uniform grain size distribution in the solid. In the first cycle, regeneration of $\mathrm{Z2T}-\mathrm{a}$ and $\mathrm{ZnO}$ was essentially complete after 40-50 minutes. Based on the final weight after regeneration, little if any zinc sulfate $\left(\mathrm{ZnSO}_{4}\right)$ was formed during regeneration. In the second cycle, the sulfidation performance of $\mathrm{ZnO}$ became worse when compared with the first cycle. As shown in Figure 2a, the sulfidation rate in cycle 2 decreased noticeably after approximately $90 \%$ conversion $(W / W o=1.06)$. In contrast, the sulfidation of $\mathrm{Z} 2 \mathrm{~T}$-a (Figure $2 \mathrm{~b}$ ) in cycle 2 was the same as in the first cycle. In the second regeneration, the performance of both $\mathrm{Z} 2 \mathrm{~T}$-a and $\mathrm{ZnO}$ became slightly worse. After $40-50 \mathrm{~min}$, regeneration of both $\mathrm{Z} 2 \mathrm{~T}-\mathrm{a}$ and $\mathrm{ZnO}$ was about $95 \%$ complete.

\section{Work Forecast for Next Quarter}

A journal article on "the Sulfidation of Zinc Titanate and Zinc Oxide Solids" will be written and submitted for publication. Work on the modeling of $\mathrm{Zn}-\mathrm{Ti}-\mathrm{O}$ sulfidation will be completed.

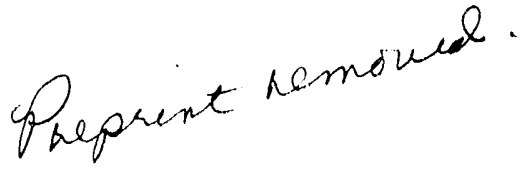

\section{DISCLAIMER}

This report was prepared as an account of work sponsored by an agency of the United States Government. Neither the United States Government nor any agency thereof, nor any of their employees, makes any warranty, express or implied, or assumes any legal liability or responsibility for the accuracy, completeness, or usefulness of any information, apparatus, product, or process disclosed, or represents that its use would not infringe privately owned rights. Reference herein to any specific commercial product, process, or service by trade narne, trademark, manufacturer, or otherwise does not necessarily constitute or imply its endorsement, recommendation, or favoring by the United States Government or any agency thereof. The views and opinions of authors expressed herein do not necessarily state or reflect those of the United States Government or any agency thereof. 


\section{COMPARISON OF INITIAL SULFIDATION AND REDUCTION RATE}

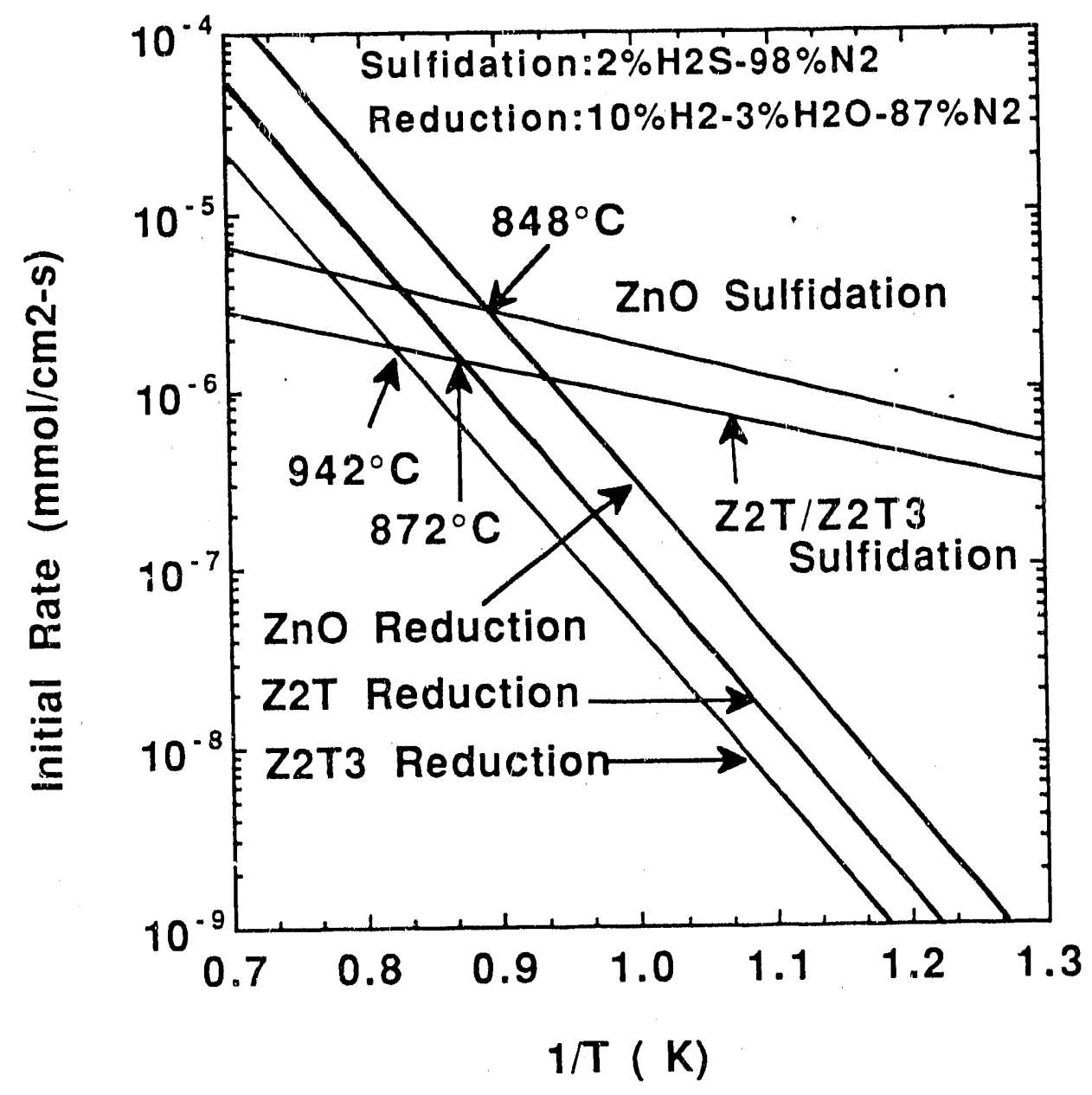

Figure 1 

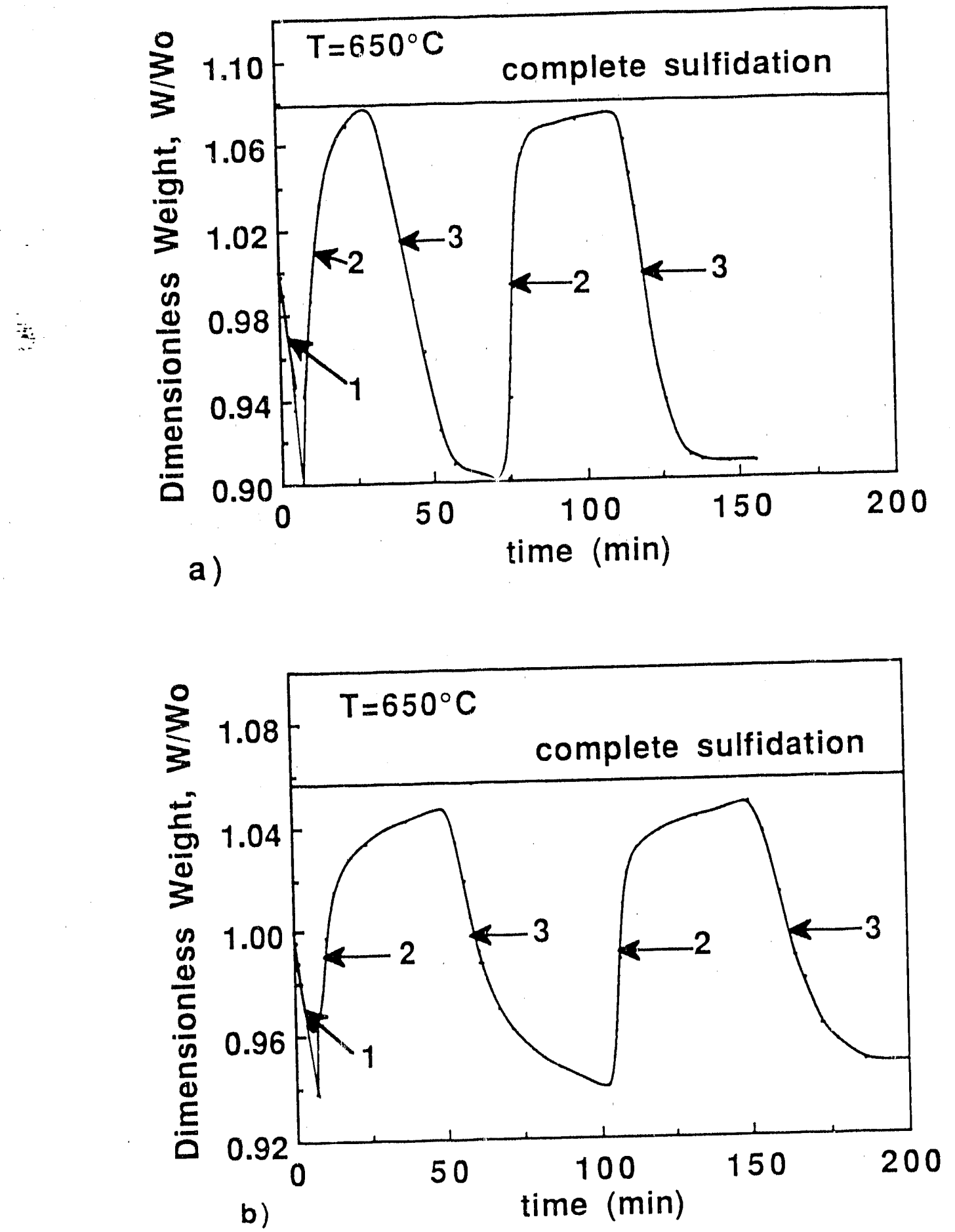

Figure 2 Sulfidation-regeneration cycles of a) $\mathrm{ZnO}$ and b) Z2T-a. 1 . Reduction in $10 \% \mathrm{H} 2-90 \% \mathrm{~N} 2 ; 2$. Sulfidation in $2 \%$ $\mathrm{H} 2 \mathrm{~S}-98 \% \mathrm{~N} 2 ; 3$. Regeneration in $21 \% \mathrm{O} 2-79 \% \mathrm{~N} 2$. 

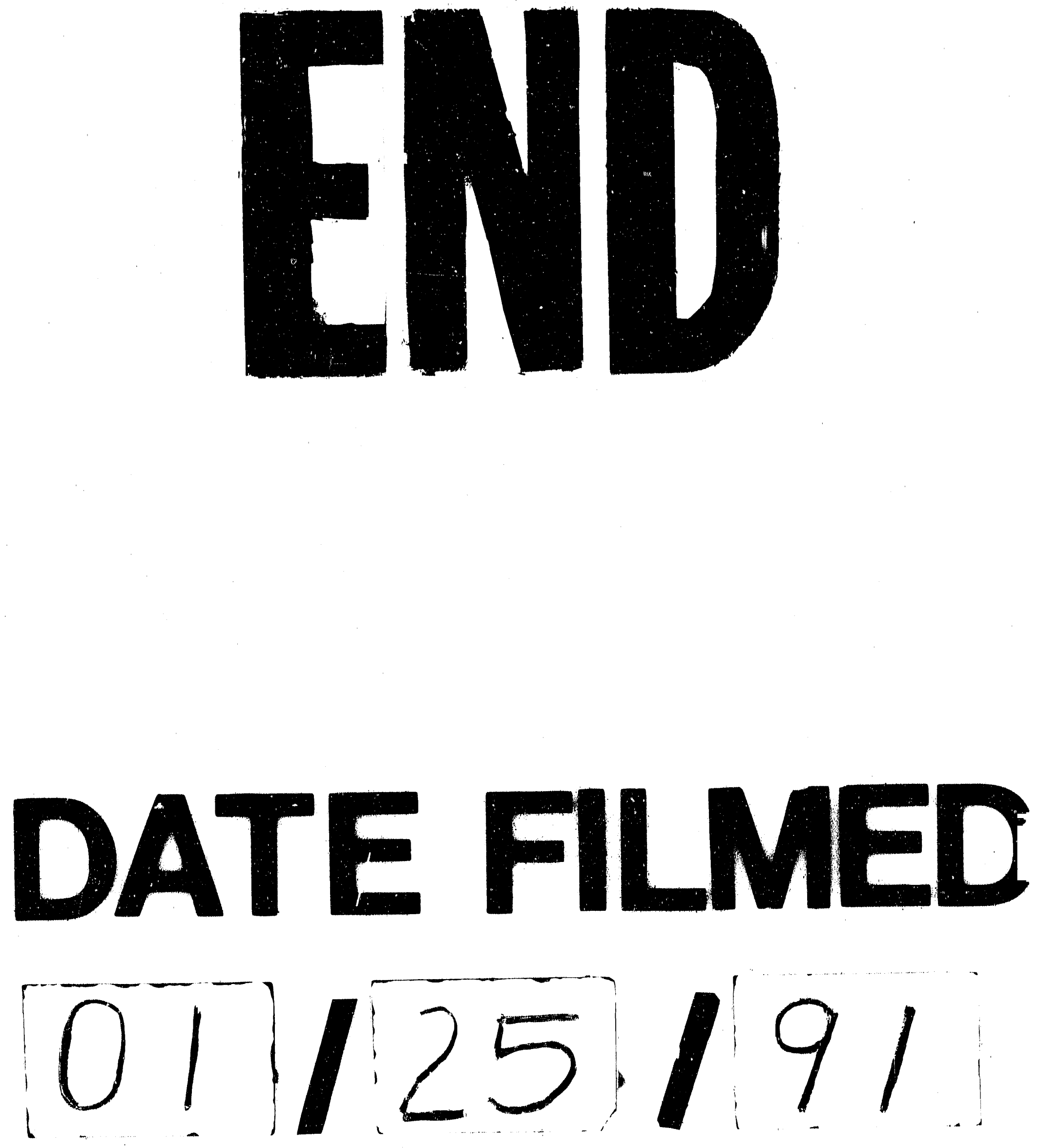
